Paideusis

\title{
Law and Disorder: Ontario Catholic Bishops' Opposition to Gay-Straight Alliances
}

\section{Tonya D. Callaghan}

Volume 22, Number 1, 2014

Sexual and Gender Diversity in Schools

URI: https://id.erudit.org/iderudit/1071463ar

DOI: https://doi.org/10.7202/1071463ar

See table of contents

Publisher(s)

Canadian Philosophy of Education Society

ISSN

0838-4517 (print)

1916-0348 (digital)

Explore this journal

Cite this article

Callaghan, T. (2014). Law and Disorder: Ontario Catholic Bishops' Opposition to Gay-Straight Alliances. Paideusis, 22(1), 28-37.

https://doi.org/10.7202/1071463ar
Article abstract

Originating in the United States, a Gay/Straight Alliance (GSA) is an in-school student club whose focus is on making the school a safe space for lesbian, gay, bisexual, transgender and queer students and their straight allies by raising awareness about, and hopefully reducing, school-based homophobia. The ongoing struggle for GSAs in Canadian Catholic schools is one example of how clashes continue to be played out between Catholic canonical law and Canadian common law regarding sexual minorities. This paper draws upon Foucault's Discipline and Punish: The Birth of the Prison, and The History of Sexuality Vol. 1: An Introduction to analyze one particularly influential curricular and policy document entitled Pastoral Guidelines to Assist Students of Same-Sex Orientation from the Ontario Conference of Catholic Bishops. This paper posits that Catholic doctrine about non-heterosexuality functions as a Foucaultian Panopticon enabling Catholic education leaders to observe and correct the behaviour of non-heterosexual teachers and students that they deem runs counter to the values of the Vatican. This paper argues that successful resistance to the powerful disciplining regime of the Catholic school is possible.
This document is protected by copyright law. Use of the services of Erudit (including reproduction) is subject to its terms and conditions, which can be viewed online.

https://apropos.erudit.org/en/users/policy-on-use/ 
Paideusis, Volume 22 (2014), No. 1, pp. 28-37

\title{
Law and Disorder: Ontario Catholic Bishops' Opposition to Gay-Straight Alliances
}

\author{
TONYA D. CALLAGHAN \\ Werklund School of Education, University of Calgary
}

\begin{abstract}
Originating in the United States, a Gay/Straight Alliance (GSA) is an in-school student club whose focus is on making the school a safe space for lesbian, gay, bisexual, transgender and queer students and their straight allies by raising awareness about, and hopefully reducing, school-based homophobia. The ongoing struggle for GSAs in Canadian Catholic schools is one example of how clashes continue to be played out between Catholic canonical law and Canadian common law regarding sexual minorities. This paper draws upon Foucault's Discipline and Punish: The Birth of the Prison, and The History of Sexuality Vol. 1: An Introduction to analyze one particularly influential curricular and policy document entitled Pastoral Guidelines to Assist Students of Same-Sex Orientation from the Ontario Conference of Catholic Bishops. This paper posits that Catholic doctrine about non-beterosexuality functions as a Foucaultian Panopticon enabling Catbolic education leaders to observe and correct the behaviour of non-heterosexual teachers and students that they deem runs counter to the values of the Vatican. This paper argues that successful resistance to the powerful disciplining regime of the Catholic school is possible.
\end{abstract}

Publicly-funded Canadian Catholic schools are part of an historical separate school system enshrined in the Canadian Constitution (1867) and are operated by a civil authority called a separate school board comprised of municipally elected school trustees. Because of trustees' publicly-elected status, Canadian Catholic schools are therefore legally accountable to provincial governments rather than church authorities. Canadian Catholic schools do have a constitutionally protected mandate to offer educational policy and curriculum in keeping with Catholic canonical law, or doctrine, but these elements of Catholic education must not clash with Canadian common law and the Canadian Charter of Rights and Freedoms (1982). For example, when Catholic education leaders are trying to decide whether or not to allow Gay/Straight Alliances (GSAs) ${ }^{1}$ to be established in their schools, they must ensure they are also abiding by Canadian common law and not just Catholic canonical law. Catholic canonical law is not the only authority in Canadian Catholic schools; Canadian common law is also a legitimate authority that holds legal supremacy and therefore should be equally respected (Callaghan, 2012).

\footnotetext{
1 Originating in the United States, a GSA is an in-school student club whose focus is on making the school a safe space for lesbian, gay, bisexual, transgender and queer (LGBTQ) students and their straight allies by raising awareness about, and hopefully reducing, school-based homophobia.

(C) Copyright 2014. The author, Tonya Callaghan, assigns to Paideusis the right of first publication and educational and non-profit institutions a non-exclusive license to use this document for personal use and in courses of instruction provided that the article is used in full and this copyright statement is reproduced. Any other usage is probibited without the express permission of the author.
} 
For those unfamiliar with Catholic doctrine, the central contradiction related to the behaviour of nonheterosexuals can be distilled to the colloquial Christian expression: "Love the sinner, hate the sin." This irreconcilable concept underlies curricular and policy decisions regarding the topic of sexual diversity and the existence of sexual minorities in Canadian Catholic schools. Interestingly, Canadian Catholic education leaders tend to enforce infractions having to do with Catholic doctrine related to sexual diversity more than other elements of the doctrine pertaining to sexuality. For example, Catholic teachers working for a Canadian Catholic separate school board must sign an employment contract containing a Catholicity clause requiring them to uphold all elements of Catholic doctrine 24 hours a day, seven days a week, but the non-heterosexual teachers are the ones most held to account. Specifically, lesbian and gay teachers in Catholic schools are summarily dismissed for legally marrying their same-sex partners, or for wanting to raise children with their same-sex partners (Callaghan, 2012). Conversely, heterosexual teachers are not subjected to summary dismissals for similar doctrinal infractions. This is evident by the fact that Catholic doctrine also forbids the use of contraception and divorce, yet it appears that a high percentage of married heterosexual teachers are keeping their jobs in spite of deciding not to have children, or in spite of having miraculously small families of only two or three children, or in spite of getting divorced. In this paper, I illustrate how clashes between Catholic canonical law and Canadian common law regarding sexual minorities are played out in Canadian Catholic schools.

Foucault's work ${ }^{2}$ is useful in analyzing the very influential curricular and policy document entitled Pastoral Guidelines to Assist Students of Same-Sex Orientation (2004) released by the Ontario Conference of Catholic Bishops. In his genealogical stage, Foucault was concerned with the workings of power and describing what he calls a "history of the present" in order to discover how our current situation originated, especially in relation to contemporary concerns. Even though the concept of the individual is deeply problematic for Foucault, the specific relationship between the individual and the institution reveals how power operates most clearly. I argue that Catholic doctrine about non-heterosexuality functions as a Panopticon that enables Catholic education leaders to observe and correct the behaviour of non-heterosexual teachers and students that they deem to have deviated from the values of the Vatican.

\section{Students Agitate for a Bona Fide GSA in Ontario Catholic Schools}

In March 2011, a group of students at St. Joseph's Secondary School in Mississauga, Ontario provoked a significant battle for Canadian LGBTQ rights by requesting permission to establish a GSA in their school (Baluja \& Hammer, 2011; Houston, 2011). The student activists, led by a then 16-year-old Grade 11 student, Leanne Iskander, were repeatedly denied in their requests for a GSA in their Catholic school, and their agitation caused serious consternation not only for the administrators of St. Joseph's, but also their school district, the Ontario bishops, and the Ontario provincial government (Collins \& Kirby, 2011; Galloway, 2011; Houston, 2011; Kostoff \& Abbruscato, 2011). ${ }^{3}$

The students carried on their fight into the next academic year, and vowed to continue their push for a bona fide GSA rather than the watered-down version known as a By Your SIDE Space (an acronym for Safety, Inclusivity, Diversity, and Equity). Ontario's Halton Catholic District School Board leaders reluctantly proposed By Your SIDE Spaces as a Catholic alternative to GSAs after much pressure and debate from Catholic students, Canadian human rights and civil liberties groups, the media, and members of the general public (Brown, 2011).

\footnotetext{
2 See, in particular, Discipline and Punish: The Birth of the Prison (1975/1995) and The History of Sexuality Vol. 1: An Introduction (1976/1978).

${ }^{3}$ Iskander's fight for a GSA was reported in the Canadian news media including The Globe and Mail. It also reached international news outlets such as the British Pink News and the American The Advocate, which have recounted Iskander's attempts to establish a club where she and her friends could be freely LGBTQ, and use gay pride symbols such as rainbows to promote their club, just as students are able to do in non-Catholic public schools (Baluja \& Hammer, 2011; Garcia, 2011; Geen, 2011).
} 
Some Ontario Catholic education leaders accepted By Your SIDE Spaces and other general equity clubs in Catholic schools on the following conditions: they did not use the word "gay" anywhere in their title; they were not student-led; and, if they did address issues facing sexual minorities, they would focus mainly on Church teaching regarding homosexuality and the problem of homophobic bullying among students, rather than the anti-homophobia activism and LGBTQ pride that typify Gay/Straight Alliances. Catholic education leaders recommended that LGBTQ students struggling with their sexual orientation or gender identity and their Catholic identity seek one-to-one support for "their personal and pastoral needs" through their Catholic school's counseling and chaplaincy programs rather than through student support groups such as Gay/Straight Alliances (Council of Catholic School Superintendents of Alberta, 2007, section 8).

\section{The Catholic Doctrine at the Root of the Catholic Version of a GSA}

Students in Ontario Catholic schools receive information on non-heterosexuality from Catholic educators, counselors, and school chaplains who have been trained to manage sexual minorities in Ontario Catholic schools through workshops about the Ontario Conference of Catholic Bishops' (OCCB, 2004) curriculum and policy document called Pastoral Guidelines to Assist Students of Same-Sex Orientation (PGASO). A pastoral guideline is normally a sanctioned letter from a bishop, or group of bishops, outlining official policy on a particular topic involving the moral care of a congregation. The PGASO is a pastoral guideline commissioned, written, and approved by Ontario bishops for mandatory use in Ontario Catholic schools. It is a little-publicized document that nevertheless has had a powerful influence on the educational policy and curriculum decisions that Catholic education leaders make regarding sexual minority groups in their schools.

The purpose of the PGASO is to clarify for educators the official teaching of the Roman Catholic Church on the topic of homosexuality, to promote the "virtue of chastity" for sexual minorities who are referred to in Catholic parlance as "persons with same-sex attraction," and to advance the Catholic school as the "centerpiece of apostolic ministry to students experiencing same-sex attraction" (OCCB, 2004, p. 11). The PGASO circulates the most egregious elements of Catholic doctrine about non-heterosexuality, such as excerpts from the Catechism of the Catholic Church that describe "homosexual acts" as "intrinsically disordered" and as "acts of grave depravity" that are on the list of "sins gravely contrary to chastity" (cited in OCCB, 2004, p. 53). The PGASO stresses the Catholic doctrinal directive that non-heterosexual lay Catholics must remain celibate for the rest of their lives. To assist non-clergy LGBTQ Catholics in following through with this required celibacy, the PGASO recommends the corrective Twelve-Step program Courage as a reputable method for arresting same-sex desire or even transforming non-heterosexual orientations into the morally acceptable heterosexual orientation (Courage Apostolate, 2011; OCCB, 2004, p. 14).

The authors of the PGASO state that they are aware of the legal obligation Ontario Catholic schools have to uphold Canadian law impacting sexual minority groups in public schools, yet they have designed a pastoral guideline that encourages Catholic schools in Ontario to disregard these very elements in Canadian law. Specifically, the Canadian law being violated here is Section 15, the equality rights provision, of the Canadian Charter of Rights and Freedoms (1982), which protects against discrimination on the basis of sexual orientation. By disregarding Canadian law in this way, the PGASO does not assist LGBTQ students in Ontario Catholic schools at all; on the contrary, it encourages further homophobic discrimination to be leveled against them. This kind of homophobic curricular and policy document does not encourage a safe and caring environment for sexual minority groups in Ontario Catholic schools, yet few people know of its existence and problematic function in such schools-hence, the need for further studies into this little-known aspect of Canadian schooling. Indeed, Catholic school jurisdictions across Canada have been chary about engaging in and publishing results of studies about homophobia in their schools. ${ }^{4}$ School-based research ${ }^{5}$

\footnotetext{
${ }^{4}$ See, for example, the barriers Taylor and Peter (2011) encountered in their attempts to include Catholic schools in their Canadian study:
}

Although we discussed implementation with officials from several Catholic divisions who were clearly interested in participating, they were instructed not to participate by their governing Bishops' councils, 
points to a systemic and active, school board-approved and church-sanctioned homophobia occurring in publicly-funded Canadian Catholic schools. This type of oppression represents one mode of power-the dominating control and authority that groups or institutions can have over others. Resistance to oppression represents another mode of power- the personal potential inherent in the everyday relations between people and institutions. Foucault's theory of disciplinary surveillance (1975/1995) helps explain the phenomenon of homophobia in Catholic school.

\section{Foucault's Theory of Disciplinary Surveillance}

In Discipline and Punish, Foucault draws upon the work of $18^{\text {th }}$ century British utilitarian philosopher Jeremy Bentham (1748-1832) who describes the Panopticon as an architectural device that can be used in institutions such as prisons to observe all the prisoners without the observer being seen. Prisoners never know whether or not they are being observed and, therefore, must act as though they are always being observed. The power of the Panopticon is its ability to cause those being observed to discipline themselves and to "induce [within them] a state of conscious and permanent visibility that assures the automatic functioning of power" (Foucault, 1975/1995, p. 201). The Panopticon is a useful metaphor for the doctrinal disciplining of nonheterosexuals in Ontario Catholic schools.

Two teacher participants in the Holy Homophobia study (Callaghan, 2012), who were assigned the pseudonyms "Mark" and "Luke," continue to be employed by their Catholic school boards because they have been able to hide the fact that they live with their respective male partners. Their lesbian and gay colleagues who cannot hide their legal marriages, or the children they are raising within those marriages, are often dismissed because they are deemed to be living in ways that are contrary to Catholicity (Callaghan, 2012). As discussed in the introduction to this paper, heterosexual teachers who are also contrary to Catholicity because they go against Catholic doctrine by using contraception or by getting divorced are not subject to the same kind of discipline. Mark and Luke, however, experience the disciplinary gaze of Catholic doctrine while at work, and, in some instances, even at home. Foucault (1975/1995) describes the efficiency of the Panopticon's power:

He who is subjected to a field of visibility, and who knows it, assumes responsibility for the constraints of power; he makes them play spontaneously upon himself; he inscribes in himself the power relation in which he simultaneously plays both roles; he becomes the principle of his own subjection. (pp. 202-203)

apparently on the grounds that generic safe-schools policies protect all students equally, and that Catholic schools should not be involved in activities that affirm the viability of a "homosexual lifestyle," such as filling out a homophobia survey. As a result, we do not have enough participants from Catholic school boards to be able to report on the situation there with the same high level of confidence that we have in the findings of the rest of this report. There is nothing in the data that we do have to suggest that the situation facing LGBTQ students and students with LGBTQ parents in Catholic schools is better than in non-Catholic schools, and much to suggest that it is even worse. (p. 132)

5 Holy Homophobia (Callaghan, 2012) examines three data sets: 1) the experiences of 20 LGBTQ participants-13 students and 7 teachers_each from 10 Catholic schools in Alberta and 10 Catholic schools in Ontario; 2) news media accounts of homophobia occurring in Catholic schools throughout the provinces of Alberta and Ontario; and 3) Catholic documents written to clarify for Catholic educators in the provinces of Alberta and Ontario the official Catholic doctrine about non-heterosexuality. This study is informed by the epistemology of critical theory, which traces injustices to their source by revealing the institutional structures and processes that perpetuate inequality in educational practice (Gibson, 1986). Drawing upon selected critical theories is helpful in constructing an account of homophobia in Catholic schools that goes beyond participant experience and textual evidence. 
Foucault's use of the male pronoun here suggests a casual sexism that was prevalent in his cultural milieu at the time he was writing. Scholars who draw upon Foucault's work in the $21^{\text {st }}$ century should address the androcentrism that is evident in his analysis of the male experience as well as the tacit implications of his sexist language. Although Foucault is writing about a male subject in the above quotation, the experience of being a part of one's own subjection is applicable to females and transgender persons as well.

Mark and Luke become the "principles of their own subjection" by monitoring and adjusting their own behaviour to ensure that it outwardly appears to conform to Catholic doctrine. Luke, for example, stopped inviting his long-term partner to any school functions because it had become too difficult to pretend they were not a couple. Because he is a principal, the disciplinary constraints around Mark are tighter than those around Luke. Part of Mark's role as a principal requires him to host staff barbecues and other colleaguebonding events at his home. Mark explained to me that, in order to prepare for such hosting duties, he has to "de-gay the house ... do a major sweep" so that the evidence of his refusal to conform to the celibacy requirement of Catholic doctrine for non-heterosexuals will not be detected by any of his guests who might have the power to have him fired. Both Mark and Luke harbour similar "nightmare scenarios" of being turned in to the authorities by someone, and they both worry that their nightmares might one day be transformed into the reality of losing their livelihoods.

Mark and Luke must be ever-vigilant about the information they reveal about themselves at school and elsewhere in order to avoid being reported to Catholic authorities. This form of disciplining surveillance is not entirely successful, however, as Luke is able to be open about his sexuality with select colleagues at work, and he is also able to express his commitment to social justice activism through various acts of subversion. Furthermore, both Luke and Mark are not totally dominated by the doctrinal disciplining of their Catholic schools in that they each have a long-term partner with whom they live, despite the fact that this is decidedly against Catholic doctrine. Through the power of personal will, Mark and Luke have managed not to fully internalize the disciplining gaze of the Panopticon. However, there are likely many more closeted teachers who have internalized the gaze, and so have been effectively silenced, and, sadly, continue to silence themselves to remain employed.

\section{Catholic Doctrine as Foucaultian Panopticon}

The authority that enables and facilitates the firing of LGBTQ teachers in Catholic schools who violate Catholic doctrine about non-heterosexuality by living with their same-sex partners or by raising children is traceable to various pieces of Catholic doctrine developed by the Vatican and reproduced in the Ontario Bishops' pastoral guideline that is required reading in all Ontario Catholic schools. The goal of such Catholic doctrine is to "guide others away from the practice of homosexual genital activity" (OCCB, 2004a, p. 25). The Catholic doctrine on non-heterosexuality is itself a Panopticon in the sense that those who fully believe in its message can use it as guide when scanning the behaviour of others, or even themselves, to determine if their behaviour conforms to the expectations of Catholic doctrine. If an individual's behaviour is found lacking, such as when a gay man who teaches in a Catholic school legally marries his male partner, then the doctrine functions as a kind of "law" that can be enforced by terminating his employment. In this way, Catholic doctrine about non-heterosexuality functions like a Panopticon that enables Catholic education leaders to observe and correct any LGBTQ behaviour that they deem to counter the values of the Vatican.

Another example that illustrates this point comes from the Durham Catholic District School Board in Southern Ontario, which in 2002 attempted to prevent a student named Marc Hall from taking his boyfriend to his high school graduation dance (Canadian Broadcasting Corporation [CBC] News, 2002; Oziewicz, 2002). The principal of Monsignor John Pereyma Catholic Secondary School, a publicly-funded separate school in Oshawa, had refused Hall permission to take his boyfriend to the prom on the grounds that interacting with a same-sex partner at the prom would constitute a form of sexual activity that was contrary to Catholicity (MacKinnon, 2002). Prior to his raising the issue of whether or not same-sex dates were welcome at the very public and school-sanctioned prom dance, Hall did not attract the disciplinary gaze of his school administrators. They may have known he was gay, but according to Catholic doctrine, being gay is not a problem. Being gay only becomes a problem when gay people start behaving in ways that would lead to 
"homosexual genital activity" (OCCB, 2004a, p. 25). In my most recent study Holy Homophobia, I found that students are relatively freer to be queer within Catholic school environments compared to queer teachers and staff. That is to say, teachers who are found to be actively LGBTQ are regularly dismissed from the schools; LGBTQ students, on the other hand, are rarely removed from schools although they are certainly policed by school administration in other ways.

Once Hall asked for permission to take his boyfriend to the prom, his Catholic school administrators had to examine his request through the filter of Catholic doctrine. Here, the doctrine functioned as a Panopticon-a tool used to closely examine Hall's request in order to determine if what Hall was proposing would conform to Catholicity. The administrators concluded that a gay schoolboy who has a boyfriend, and who proposes to dance with his boyfriend in a public way at a graduation dance sanctioned by the Catholic school, is behaving contrary to Catholicity and so they refused Hall's request. However, he managed to escape the disciplining gaze by appealing to another authority that in a limited fashion also governs Ontario Catholic schools-Canadian anti-discrimination law-and it was in so doing that he successfully obtained an interlocutory injunction that enabled him to take his boyfriend as his date to the prom (MacKinnon, 2002). Therefore, when Catholic doctrine is used as a kind of Panopticon scanning tool with Catholic school students (as opposed to teachers), it is limited in its ability to uncover, expose, and discipline its subjects precisely because of the counter force of the Canadian law-another authority that should be as respected in Catholic schools.

\section{Foucault and Resistance}

One problem in drawing upon Foucault's Discipline and Punish to examine how homophobia is exercised in Catholic schools is that the individual appears to be subjected to the point where resistance to disciplinary practices appears futile. To begin to imagine the possibility of resisting an oppressive regime, we need to turn to his The History of Sexuality Vol. 1: An Introduction (1976/1978). Here he explores how the Victorian period's characteristic repression of sexuality actually "speaks verbosely of its own silence" (p. 8) in that it ushered in a new set of discourses on questions of sexual expression while under the guise of a forced silence on the topic. In the oxymoron of articulated silence, Foucault points to both repressive and productive elementsrepressive in the sense that certain structural measures are put in place in an effort to control sexual expression, and productive in the sense that these very obstacles invite new forms of behaviour that effectively subvert attempts at disciplining control.

I suggest that the Vatican tries to control the lived expression of non-heterosexuality by disseminating Catholic doctrine on the topic in Catholic schools. In their persistent refusal to recognize non-heterosexuality (and its various sub-categories) as a legitimate sexual orientation, the Vatican and Catholic schools make themselves obligated to define and to "take great pains to relate in detail the things it does not say" (Foucault, 1976/1978, p. 8). The pastoral guidelines outlining what constitutes unacceptable same-sex behaviour, in effect, result in the Catholic Church declaiming at length on something it does not wish its followers to endorse or condone. More and more, the Catholic Church is obligated to defend and explain its positionthereby elaborating even more on a topic it does not want to address.

The Vatican also tries to control any objection to its homophobic message by limiting discussions about homophobia in Catholic schools to those instances of homophobic bullying that occur among students, and by circulating incomplete definitions of homophobia that do not implicate the Vatican itself as a major contributor to homophobic discrimination. Some students and teachers in Catholic schools respond to these silencing attempts by taking part in research studies and by also taking their stories to the media. The repressive silencing that arises from being a non-heterosexual student or teacher in a Canadian Catholic school makes LGBTQ students and teachers quite literally "verbose" on their own institutional silencing. However, the experiences of the participants in such studies (Callaghan, 2012) show that the repressive force of doctrinal disciplining is often more powerful than its productive force. That is, "productive" in the sense of power that invites new forms of action and occurrences, rather than the familiar form of repressive power 
that concentrates on constraining individuals and limiting freedom. ${ }^{6}$ Of the seven teacher participants in one study (Callaghan, 2012), four have been ousted from their jobs in Catholic schools for behaving in ways deemed contrary to Catholicity related to sexuality and gender identity, and the majority of student participants were either closeted about their non-heterosexuality or "outed" against their will by school administrators and bullies. Nevertheless, I would suggest that the productive force of doctrinal disciplining is discernible in the existence of pastoral guidelines that the Catholic bishops have had to write in order to regulate non-heterosexuality in Catholic schools, which, in turn, have invited various acts of subversion on the part of some of the participants in my study who resisted the homophobic repression that pervades their Catholic schools.

\section{Catholic Dissent and Other Resistance to Homophobic School Policies}

In my research, I encountered many Catholic education leaders, educators, counselors, and parents who do not agree with Catholic school policies regarding sexual minorities. Increasingly, many of these lay Catholics are stepping forward to express their opposition to institutionalized homophobia in Canadian Catholic schools. Indeed, there is a rich historical tradition of dissent from the Church's teachings regarding many issues among both Catholic clergy and laity, and this is certainly true about homosexuality (Callaghan, 2007b; McDonough, 2012; McNeill, 1993). But Catholic doctrine-not Catholic dissension-tends to drive school policy on controversial topics such as non-heterosexuality under the direction of local bishops who are ultimately answerable to the Vatican (Bryk, Lee, \& Holland, 1993; Callaghan, 2007a).

Knowing that a By Your SIDE Space is meant to be a general equity club and that any discussion of non-heterosexuality would have to be filtered through conservative Catholic doctrine on the matter, Iskander and her classmates refused to accept this Catholic version of a GSA and continued to agitate for a bona fide GSA in their school. The tremendous transformative power of queer resistance came to fruition for these young queer activists and their allies when their efforts culminated in the passing of Bill 13, the Accepting Schools Act, in June 2012. This bill attempts to reduce school-based homophobic bullying by mandating that all Ontario schools_-including publicly-funded, faith-based schools_-must allow students to establish Gay/Straight Alliance support groups (Houston, 2012). Bill 13 includes a notable provision that requires schools to allow students to use the word "gay" in the name of their GSA (Houston, 2012). This provision was necessary because Catholic education leaders have been resistant to GSAs, and especially the use of the word "gay" and other celebratory symbols such as the rainbow pride flag, because they are considered too affirming of non-heterosexuality. The widespread acceptance of Bill 13 shows that Ontarians recognize that the Roman Catholic Church is not the only authority on Catholic education in Ontario. Thus, seemingly powerless LGBTQ teenagers, through their tenacity and perseverance in their fight against homophobic oppression, have been able to effect social change.

There may be a centralized directive from Ontario Catholic bishops to keep GSAs out of Ontario Catholic schools, but not all Catholic schools have to follow it. Resistance is possible even in the overly hierarchical structure of Catholic schools. This is evidenced by the story of Windsor-Essex Catholic District School Board in Southwestern Ontario, which became the first Catholic board in Ontario to allow secondary students to form Gay/Straight Alliances and to name them as such (CBC News, 2012). Commenting on Bill 13's new bullying and discrimination amendments to Ontario's School Act, Windsor-Essex Superintendent, Mike Seguin, recognized the Roman Catholic Church was not the only authority on Catholic education in Ontario: "Our position is to be fully compliant with the law. We're law-abiding citizens and it's important as adults and as leaders in the school system to show that and to follow the mandate based on the Bill 13 guidelines" (cited in CBC News, 2012, p. 1). Even in the face of seemingly immutable structures, such as the Catholic hierarchy that directs Catholic education in Canada, change is possible, and secular remedies

\footnotetext{
${ }^{6}$ For details on how Foucault breaks from his teacher Louis Althusser and the Marxist notion of power as solely repressive, see his descriptions of power as positive and productive in his public address called Two Lectures and in an interview with him about truth and power, both of which are collected in a series of essays called Power/Knowledge $(1972 / 1980)$.
} 
involving Canadian legislation and the law can be effective in combating homophobia, and dissenting Catholic voices can find expression.

\section{Conclusion}

Student activists such as Marc Hall and Leanne Iskander are the leading dissenting voices that have brought the clashes between Catholic canonical law and Canadian common law regarding sexual minorities to the attention of the Canadian public. Their struggles to have their Catholic school administrators respect the equality rights provision of the Canadian Charter of Rights and Freedoms have shed light on the homophobic policies and practices occurring in Canadian Catholic schools. Even though Roman Catholicism is the largest religious faith in Canada, many Canadians are unaware of Catholic doctrine regarding the topic of sexual minorities and how that doctrine is disseminated and expressed as policy in Canadian Catholic schools. An examination of the Ontario bishops' obscure yet influential curricular and policy document entitled Pastoral Guidelines to Assist Students of Same-Sex Orientation (PGASO) shows how homophobia is institutionalized in Catholic schools. The PGASO reveals how Catholic doctrine about non-heterosexuality produces LGBTQ students and teachers as "persons with same-sex attraction" whose behaviour should be closely monitored, controlled and disciplined. Homophobic Catholic doctrine functions as a Foucaultian Panopticon, or scanning device, that Catholic administrators use to monitor and modify the behaviour of sexual minorities deemed to be in violation of the values of the Vatican. Foucault's Panopticon theory offers a partial explanation of the repressive force of the power of Catholic doctrine and its ability to monitor and correct students' and teachers' behaviour in Catholic schools. Foucault also theorizes the productive force of power, which can explain how the overwhelming heteronormativity of the Catholic school actually invites new acts of resistance. In the Canadian Catholic school context, the most effective acts of resistance are: (1) forcing Canadian Catholic bishops to write explicit pastoral guidelines outlining the Church's position on "homosexual acts of grave depravity," which they find themselves having to defend in increasingly broader terms thereby making themselves vulnerable to strong counter-arguments; (2) seeking legal remedies through the Canadian courts, as in the Marc Hall case; and (3) applying direct political action, as in the establishment of Bill 13, the Accepting Schools Act. Institutions are certainly influential in forming individuals, but Foucault shows that the relations between institutions and individuals are not only those of repression and constraint. Resistance is also possible and can be successful within power relations.

\section{References}

Baluja, T. \& Hammer, K. (2011, March 18). Mississauga high school bans gay-straight alliance. The Globe \& Mail, p. A13.

Brown, L. (2011, March 23). Halton Catholic board committee rejects gay-straight alliances: By your SIDE spaces promoted as better option. The Toronto Star. Retrieved from http://www.insidehalton.com/community/education/article/970392--the-halton-catholic-board-ison-your-side

Bryk, A. S., Lee, V. E., \& Holland, P. B. (1993). Catholic schools and the common good. Cambridge, MA: Harvard University Press.

Callaghan, T. D. (2007a, December 31). Contra/Diction: How Catholic doublespeak in Canadian Catholic secondary schools furthers homophobia. Canadian Online Journal of Queer Studies in Education, 3(1). Retrieved from https://jps.library.utoronto.ca/index.php/jqstudies/issue/view/235

Callaghan, T. D. (2007b). That's so gay: Homophobia in Canadian Catholic schools. Saarbrücken, Germany: VDM Verlag Dr. Müller.

Callaghan, T. D. (2012). Holy homophobia: Doctrinal disciplining of non-heterosexuals in Canadian Catholic schools (Doctoral dissertation). University of Toronto, Canada. Retrieved from http://hdl.handle.net/1807/32675 
Canadian Broadcasting Corporation News. (2002, May 10). Gay teen wins fight over Catholic prom. Retrieved from http://www.cbc.ca/news/canada/story/2002/05/10/hall_020510.html

Canadian Broadcasting Corporation News. (2012, August 14). Gay-straight alliance now accepted by Windsor's Catholic board. Retrieved from http://www.cbc.ca/news/canada/windsor/story/2012/08/14/wdr-gay-straight-alliance-catholicboard.html

Canadian Charter of Rights and Freedoms. (1982). Part I of the Constitution Act, 1982, RSC 1985, app. II, no. 44. Retrieved from http://laws-lois.justice.gc.ca/eng/Const/index.html

Canadian Constitution. (1867). Constitution Act, 1867, (UK), 30 \& 31 Vict, c3, RSC 1985, app. II, no. 5. Retrieved from http://laws-lois.justice.gc.ca/eng/Const/index.html

Collins, T. \& Kirby, N. (2011, April 15). Enhancement of caring for all students in the spirit of the gospel. Retrieved from www.tcdsb.org/.../OCSTA-ACBO-CatholicStudentGroups-April15-2011\%20_2_.pdf

Council of Catholic School Superintendents of Alberta. (2007, March). Toward an inclusive community. Calgary, AB: Author.

Courage Apostolate. (2011). Courage: A Roman Catholic apostolate. Retrieved from http://www.couragerc.net/Courage_Apostolate.html

Foucault, M. (1980a). Two lectures. In C. Gordon (Ed.), Power/Knowledge: Selected interviews and other writings 1972-1977 (pp. 78-108). London: Harvester Press. (Original work published 1972)

Foucault, M. (1980b). Truth and power. In C. Gordon (Ed.), Power/Knowledge: Selected interviews and other writings 1972-1977 (pp. 107-133). London: Harvester Press. (Original work published 1972)

Foucault, M. (1990). The history of sexuality, volume 1: An introduction (R. Hurley, Trans., 1978). New York, NY: Vintage Books. (Original work published 1976)

Foucault, M. (1995). Discipline and punish: The birth of the prison (A. M. Sheridan Smith, Trans.). New York, NY: Vintage Books. (Original work published 1975)

Galloway, M. (2011, June 9). Rainbow controversy. Canadian Broadcasting Corporation Metro Morning. Retrieved from http://www.cbc.ca/metromorning/episodes/2011/06/09/rainbow-controversy/

Garcia, M. (2011, June 10). Catholic school bans rainbows. The Advocate. Retrieved from http://www.advocate.com/News/Daily_News/2011/06/08/Catholic_School_Bans_Rainbows/

Gibson, R. (1986). Critical theory and education. London: Hodder and Stoughton.

Geen, J. (2011, June 10). Canadian Catholic school bans rainbows. Pink News. Retrieved from http://www.pinknews.co.uk/2011/06/10/canadian-catholic-school-bans-rainbows/

Houston, A. (2011, January 6). Halton Catholic schools ban gay-straight alliance groups. Xtra! Canada's Gay and Lesbian News. Retrieved from http://www.xtra.ca/public/Toronto/Halton_Catholic_schools_ban_gaystraight_alliance_groups9611.aspx

Houston, A. (2012, June 5). Final vote for Ontario anti-bullying bill. Xtra! Canada's Gay and Lesbian News. Retrieved from http://www.xtra.ca/public/National/Final_vote_for_Ontario_antibullying_bill12095.aspx

Kostoff, J. B. \& Abbruscato, A. (2011, March 29). An open letter to the Dufferin-Peel community regarding GSAs (Gay/Straight Alliances) in our schools. Retrieved from http://www.dpcdsb.org/cec

MacKinnon, Justice R. (2002, May 10). Smitherman v. Powers and the Durbam Catholic District School Board [Court File No. 12-CV-227705CM3]. Whitby, ON: Ontario Superior Court of Justice.

McDonough, G. P. (2012). Beyond obedience and abandonment: Toward a theory of dissent in Catholic education. Montreal, QC \& Kingston, ON: McGill-Queen's University Press.

McNeill, J. (1993). The church and the homosexual. Boston: Beacon Press.

Ontario Conference of Catholic Bishops. (2004). Pastoral guidelines to assist students of same-sex orientation. Toronto, ON: Author.

Oziewicz, E. (2002, May 11). Supreme court challenge looms: Catholic school board to take case to trial after judge overturns ban on gay prom date. The Globe and Mail, p. A4.

Taylor, C. \& Peter. T. (2011). Every class in every school: Final report on the first national climate survey on homophobia, biphobia, and transphobia in Canadian schools. Toronto, ON: EGALE Canada Human Rights Trust. 


\section{About the Author}

Tonya D. Callaghan is an Assistant Professor in the Werklund School of Education at the University of Calgary. She specializes in critical social justice and anti-oppression education. Her multiple award-winning study Holy Homophobia: Doctrinal Disciplining of Non-Heterosexuals in Canadian Catholic Schools explores Catholic resistance to anti-homophobia education in both curriculum and educational policy. Tonya can be reached at tdacalla@ucalgary.ca, and her faculty profile is available at http://werklund.ucalgary.ca/profiles/tonyacallaghan 